\title{
Evaluation of urban suitable ecological land based on the minimum cumulative resistance model: A case study from Changzhou, China
}

\author{
Feng $\mathrm{Li}^{\mathrm{a}}{ }^{\text {,*}}$, Yaping $\mathrm{Ye}^{\mathrm{b}}$, Bowen Song ${ }^{\mathrm{c}}$, Rusong Wang ${ }^{\mathrm{a}}$ \\ a State Key Laboratory of Urban and Regional Ecology, Research Center for Eco-Environmental Sciences, Chinese Academy of Sciences, Beijing 100085, China; \\ ${ }^{\mathrm{b}}$ College of Hydrology and Water Resource, Hohai University, Nanjing 210098, China \\ ' Shanghai Academy of Environmental Sciences, Shanghai 200233, China
}

\section{A R T I C L E IN F O}

\section{Article history:}

Received 30 June 2014

Received in revised form 21 August 2014

Accepted 7 September 2014

Available online 19 September 2014

\section{Keywords:}

Urban suitable ecological land

Minimum cumulative resistance model

Ecosystem services

Urbanization

\begin{abstract}
A B S T R A C T
Urbanization is accompanied by the intense transformation and conflicts among different land use types that produce a series of economic, social, and environmental impacts. Ascertaining the quantity and pattern optimization of urban ecological land is critical to solving urban environmental problems and realizing urban sustainable development. Using the Chinese city of Changzhou, an important and typical city in the Yangtze River delta, as the case study, we applied the minimum cumulative resistance model (MCRM) to calculate the amount of ecological land that meets the demand of socioeconomic development and ecological protection considerating the source of ecological land and constructed land, ecosystem services, and the resistance plane. Results showed that the suitable ecological land area is about $1006.9 \mathrm{~km}^{2}$, which is $53.8 \%$ of the total urban area of Changzhou, and is mainly distributed in Wujin and Xinbei districts. Considering the ecological land space and functional changes of the study area and comparing the current land use status with the model simulation results, we propose three land use types. For urban ecological land, positive protection measures and prohibiting economic development initiatives are necessary. For ecotones between urban developed land and ecological land, protection should be given priority and economic development activities should be rigidly controlled. For constructed land, measurements and policies should be taken to promote reasonable development and improve land intensity.
\end{abstract}

() 2014 Elsevier B.V. All rights reserved.

\section{Introduction}

Urbanization has become an inevitable trend in the 21st century (MEA, 2005a; Li et al., 2009). A highly dense and fast growing urban population, an increasing consumption demand, and the increasing ability to utilize natural resources are depleting land resources (Bohnet and Pert, 2010). To satisfy city productivity, the transformation from ecological land (e.g., arable land, forest, grassland, wetlands) to constructed land (e.g., residential, commercial, industrial land) is more intense, especially in low- and middle-income countries in Asia, Africa, and Latin America facing severe urban population pressure before industrialization (Foley et al., 2005; MEA, 2005b; Zhang et al., 2008a, 2008b).

Urbanization rate for the resident population in China reached $53.7 \%$ in 2013 (State Council, 2014), and the spatial expansion of urban land will increasingly be the main characteristic of land use

\footnotetext{
* Corresponding author. Tel.: +86 106284 9103; fax: +86 1062849103.

E-mail addresses: lifeng@rcees.ac.cn, wangrs@rcees.ac.cn, bagetutu@yahoo.cn (F. Li), yapingye66@hotmail.com (Y. Ye).
}

change in the coming decades in China (Liu et al., 2002; Seto et al., 2012). Urban expansion can be seen as a macro performance to reflect a micro mutual conversion of different types of land (Lorenz and Lal, 2009; Pauleit et al., 2005; Zhao et al., 2012). The conversion of ecological land, especially arable land, to constructed land is the most significant change in the process of urbanization (Bohnet and Pert, 2010; Qiu and Turner, 2013); more than 50\% of arable land, most of which is high-yield farmland, has been converted to constructed land (Liu et al., 2005). The expansion of urban areas and intense human activity have resulted in a decrease of ecological land along with a decline in regional ecosystem services (Costanza et al., 1997; Daily, 1997; Radford and James, 2013; Seto et al., 2012; TEEB, 2010; Wang et al., 2004). Consequently, urban land use and ecosystem services need to be integrated into the decision-making process for urban and regional sustainable development (Daily et al., 2009; Goldstein et al., 2012; Nelson et al., 2009; Viglizzo et al., 2012).

The city is a socioeconomic-natural complex ecosystem (Ma and Wang, 1984; Wang et al., 2011). Economic development is at the heart of city survival, while various activities in the urban areas would not exist without the services provided by ecological land 
(Hutyra et al., 2011; Kroll et al., 2012). Ecological land refers to the land-use type that mainly provides ecosystem services and usually includes low-intensity farmland, woodland, and water bodies. The dynamic change to ecological land area is the main factor that leads to changes in urban ecosystem services (Bai and Zhao, 2001; Chen and Shi 2005; Larondelle and Haase, 2013; Li et al., 2014). Therefore, coordinating the layout of ecological land and urban constructed land to maximize the use of constructed land without affecting ecosystem services and at the same time promoting sustainable development is a key challenge for urban planners (Yeh and Huang, 2009). However, studies on urban land use generally focus on the expansion of constructed land as the driving force of the process, while ecological land research in the urban environment is still in its infancy.
In addition, there are no guidelines on the ecological land area needed for an urban sustainable development strategy, which component of ecological land should be reserved, and where these ecological lands should be located. Defining the area and extent of ecological land is the basis for overall urban planning and land use planning, and the concept of ecological land has been proposed ( $\mathrm{Li}$ et al., 2009, 2014). In this research we use the concept of urban ecological land as defined by Li et al. (2009): urban ecological land is aimed at improving the quality of life of people in cities, protecting important ecosystems and habitats, maintaining and improving the natural and urban artificial ecological unit, and stabilizing the urban ecosystem services at a certain level. Suitable ecological land is the best suitable land area for ecosystem protection based on balancing the value of ecosystem protection and economic development in cities.

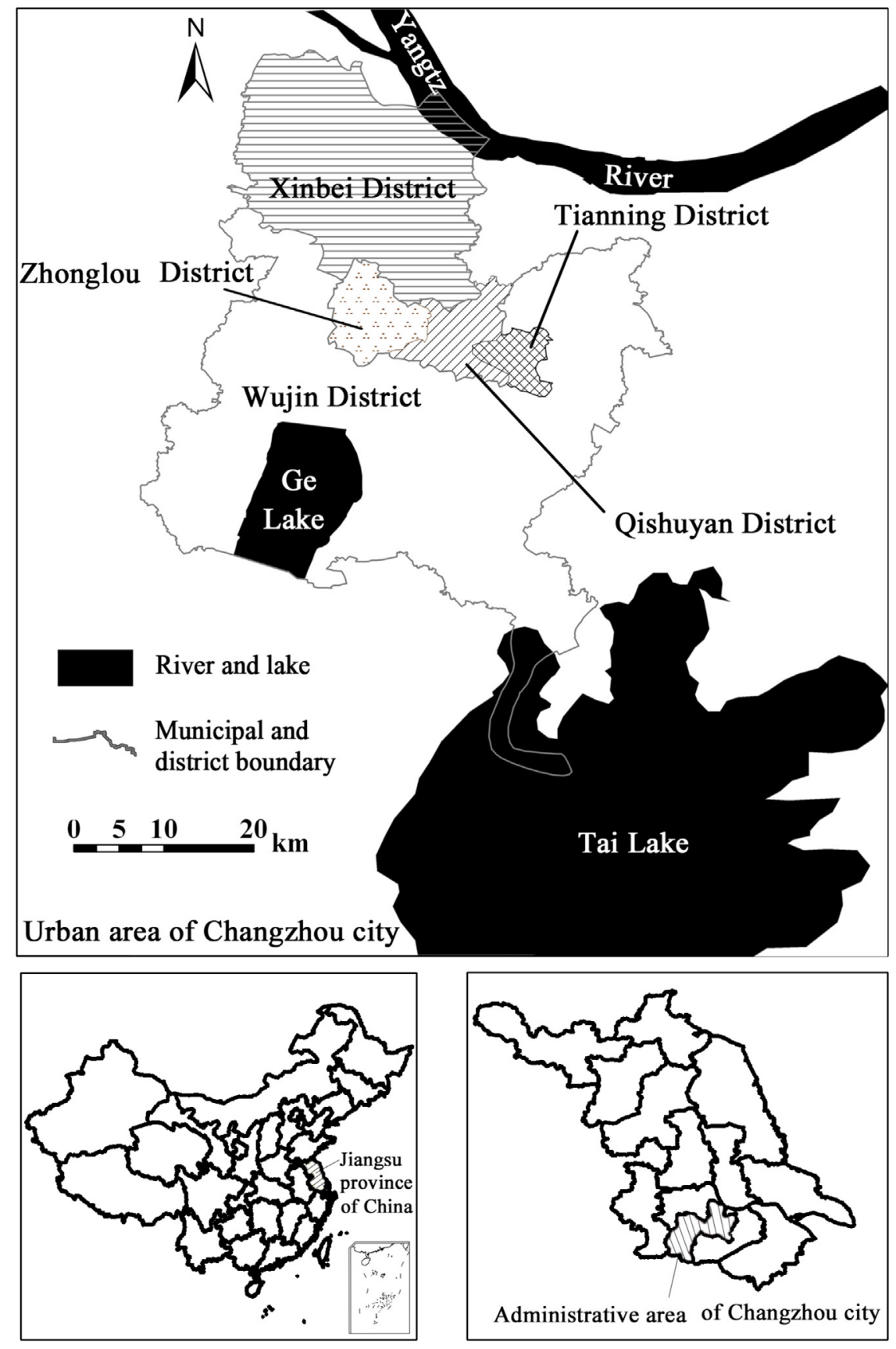

Fig. 1. Location of the study area (Li et al., 2014a). 
The models for urban ecosystem modeling can be categorized as top-down models, bottom-up models and integrated models thereof (Chen et al., 2014). The top-down models include materials/energy-oriented models (material flow analysis, energy, emergy, exergy, ecological footprint and ecosystem service models) and structure-oriented models (system dynamics, ecological network analysis and exergy-network) (Chen and Chen, 2007, 2010, 2012; Chen et al., 2007, 2010, 2011, 2014; Jiang and Chen, 2011; Jiang et al., 2009; Shao et al., 2013; Yang et al., 2010; Zhang et al., 2008a, 2008b, 2009). The bottom-up models include land use-oriented models (gravity model, market model, agentbased model, cellular model and MCRM) and infrastructureoriented models (in situ infrastructure model and life-cycle infrastructure model) (Chen et al., 2014; Knaapen, 1992).

There are some models which can be applied to assess the ecological process of landscape level. These models include habitat suitability index model (Singh et al., 2009; Wang et al., 2008), graph theoretic model (Jordan et al., 2003), network and corridor models (Nikolakaki, 2004) and weighted landscape graph model (Saura, 2010). These models can be a good simulation of landscape connectivity at the landscape scale. However, the computation of these models is quite complex and their data requirements are more stringent. There exist great limitations when these models are applied to the ecological land accounting and nature conservation area design (Knaapen et al., 1992; Wu et al., 2009).

The MCRM originated from the study of diffusion processes of species by Knaapen et al. (1992), but its application is not limited to a particular specific ecological process. Because of its simple data structure, fast algorithms, and visual results, the MCRM is regarded as one of the best tools in assessing landscape connectivity at the landscape level. In recent years, the MCRM has been applied to determine the urban ecological security pattern and in urban ecological planning (Adriaensen et al., 2003; Li et al., 2014b; Liu et al., 2010; Yu, 1999; Yu et al., 2005). Therefore, we choose the MCRM to simulate the expansion process of ecological land and construction land in this study.

Changzhou, China, is an important city in the center of the Yangtze River Delta; it is characterized by rapid urbanization and a changing spatial structure of ecological land. Using the MCRM, our research applied the resistance plane to expansion of ecological and constructed land sources in order to calculate the area of suitable ecological land needed to balance economic development and ecosystem protection. By examining the change in space and function of ecological land and comparing the current situation with the suitable ecological land, guidelines that can maintain sustainable development can be set for the development, planning, and construction of future space in Changzhou. Our research provides an important contribution to reconciling the expansion of constructed land with the protection of ecological land, coordination of urban land expansion with land conservation, and protection of urban ecosystem services and ecological quality in human settlements.

\section{Materials and methods}

\subsection{Study area}

Changzhou, China, is located in the south of Jiangsu Province and northwest of the Yangtze River Delta and the Taihu Lake plain $\left(31^{\circ} 09^{\prime}-32^{\circ} 04^{\prime} \mathrm{N}, 119^{\circ} 08^{\prime}-120^{\circ} 12^{\prime} \mathrm{E}\right.$ ) (Fig. 1$)$. The city covers $1864 \mathrm{~km}^{2}$ and has an annual average temperature of $16.3^{\circ} \mathrm{C}$, sunshine of $2035 \mathrm{~h}$ per year, annual precipitation of $1069 \mathrm{~mm}$, and 237 frost-free days. By the end of 2011, green land in the built-up area of Changzhou was $66.5 \mathrm{~km}^{2}$ (Changzhou Municipal Statistical Bureau, 2012). Currently, the structure of urban land use in Changzhou is imbalanced; the proportion of industrial land and industrial land per capita indicators are higher and the land for roads and squares, green spaces, and other infrastructure is significantly lower than the national standards. In addition, the spatial layout of land use in administrative districts is chaotic; there is no rational for the location of industrial land and residential land or land with a different nature. It is critical, therefore, that appropriate land use is optimized.

\subsection{Data sources}

We used Landsat TM data from September 18, 2006 (path/row $119 / 38$ ) as the remote sensing imagery for this study. The selected image has less than $5 \%$ cloud cover, which is representative of the season. We selected the area of interest from the 2003Changzhou City Master Plan land status map (scale 1:6000) and then applied supervised classification of the remote sensing image followed by precision calculations and fine-tuning of the local classification.

\subsection{Minimum cumulative resistance model}

\subsubsection{Principle of the model}

With respect to ecological processes, a heterogeneous landscape can be divided into a "source" or "sink" landscape, of which the source landscape consists of those processes that can promote the development of landscape types and the sink landscape consists of those processes that can prevent or delay the development of landscape types. Although source and sink landscapes have opposite qualities, a source landscape in one process may become a sink landscape in another. The main purpose of proposing the Source and Sink Landscape Theory (Chen et al., 2006) is to explore how the dynamic balance of landscape types affects ecological processes, which in turn leads to the identification of a suitable spatial pattern in every region. The transformation between source and sink occurs as a mutual conversion or as a competitive process for the control and coverage of space; this competitive process is achieved by overcoming various forces of resistance, which are then integrated to reflect the resistance surface or "plane".

The MCRM essentially reflects the degree of resistance in landscape development. The cost distance in the model differs from the actual distance and instead emphasizes the relative spatial relationship between points. This relative relationship is based on calculating the drag coefficient when the target unit passes through different landscape units. Based on the value of the minimum cumulative resistance when a target unit passes through a specific unit, we can determine the "connectivity" and "similarity" between the two units and usually the "source patch" that is the initiator of the ecological process.

To determine the minimum cumulative resistance value $M C R$, we use the following formula as modified by $\mathrm{Yu}$ and others (Yu, 1999; Yu et al., 2005):

$M C R=f_{\min } \sum_{j=n}^{i=m}\left(D_{i j} \times R_{i}\right)$

where $f$ is a function of the positive correlation that reflects the relation of the least resistance for any point in space to the distance from any point to any source and the characteristics of the landscape base surface; min denotes the minimum value of cumulative resistance produced in different processes of landscape unit $i$ transforming into a different source unit $j ; D_{i j}$ is the spatial distance between landscape unit $i$ and source unit $j$; and $R_{i}$ denotes the resistance coefficient that exists in transition from landscape unit $i$ to source unit $j$.

$R_{i}$ can be determined by the value of $i$, and the path from unit $i$ to unit $j$ produces different resistance values. When $i$ has been 


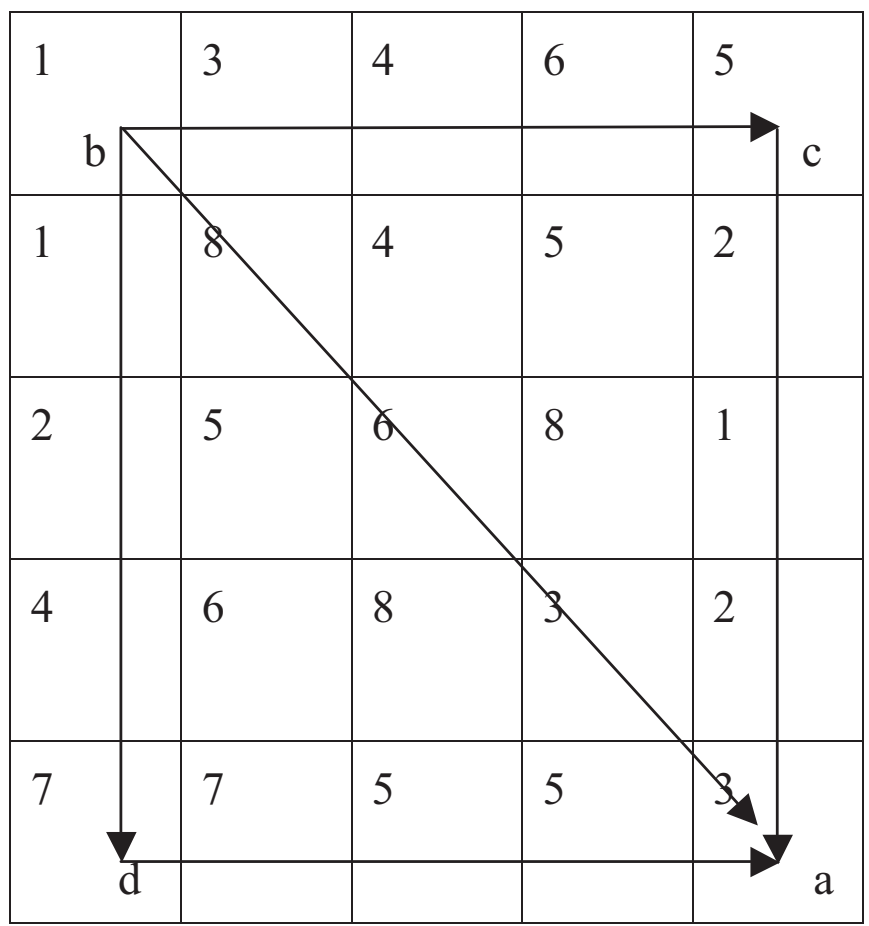

Fig. 2. Spatial distance. The value $D$ represents the spatial distance from landscape unit $b$ to source unit $a$ that defines $D_{b c a}, D_{b a}$, and $D_{b d a}$ as the space distance of the three paths. As we see from the calculations in the text, the minimum value is $D_{b a}$. The grid-map consists of the basic cell representing the unit spatial distance. The numbers in cells in this figure are set randomly to represent the resistance when passing each cell.

determined, calculating $M C R$ requires selecting the path with the least resistance value of the spatial distance. As shown in Fig. 2, the value $D$ represents the spatial distance from landscape unit $b$ to source unit $a$ that defines $D_{b c a}, D_{b a}$, and $D_{b d a}$ as the space distance of the three paths:

$$
\begin{aligned}
D_{b c a} & =\frac{(1+3)}{2}+\frac{(3+4)}{2}+\frac{(4+6)}{2}+\frac{(6+5)}{2}+\frac{(5+2)}{2}+\frac{(2+1)}{2} \\
& +\frac{(1+2)}{2}+\frac{(2+3)}{2} \\
& =25
\end{aligned}
$$$$
D_{b a}=\frac{(1+8) \times \sqrt{2}}{2}+\frac{(8+6) \times \sqrt{2}}{2}+\frac{(6+3) \times \sqrt{2}}{2}+\frac{(3+3) \times \sqrt{2}}{2}
$$$$
=19 \sqrt{2}
$$

$$
\begin{aligned}
D_{b d a} & =\frac{(1+1)}{2}+\frac{(1+2)}{2}+\frac{(2+4)}{2}+\frac{(4+7)}{2}+\frac{(7+7)}{2}+\frac{(7+5)}{2} \\
& +\frac{(5+5)}{2}+\frac{(5+3)}{2} \\
& =33
\end{aligned}
$$

As we see from these calculations, the minimum value is $D_{b a}$, so the path with the minimum resistance value from landscape unit $b$ to source unit $a$ is $D_{b a} \times R_{b}$.

In urban areas, the protection-expansion process of ecological land and the development-expansion process of constructed land co-exist. Ecological land is the source for the protection and expansion process of ecological land (Fig. 3A), whereas constructed land is the source for the expansion process of constructed land (Fig. 3B). In Fig. 3, P and L denote the cumulative resistance curve of the expansion of constructed land and ecological land, respectively, and $\mathrm{C}$ is the balance line between the two processes. Between

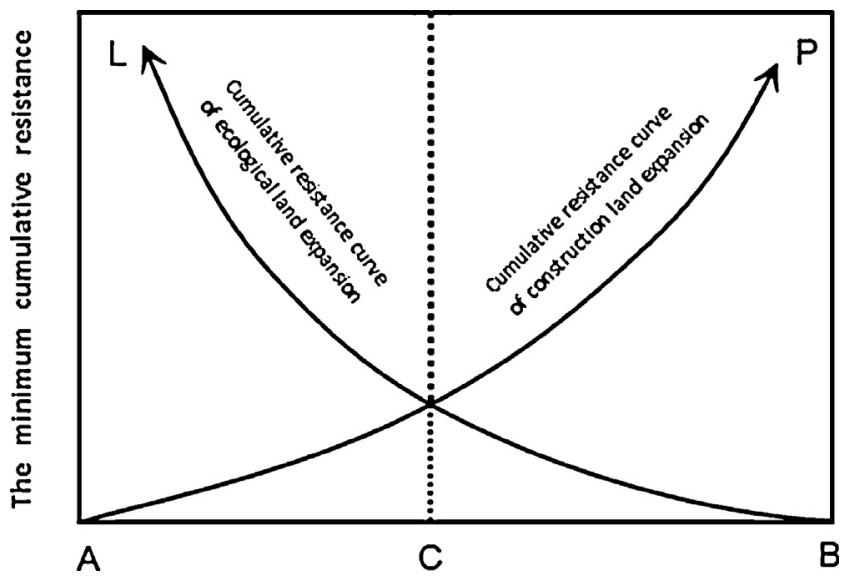

Fig. 3. Balance of constructed land and suitable ecological land based on the minimum cumulative resistance model (modified from Liu et al., 2010).

AC, the MCR of ecological land is greater than the MCR of constructed land, which facilitates expansion of constructed land and makes this area suitable for development. Conversely, between $\mathrm{CB}$, the area is suitable as ecological land.

Based on the resistance process of the two land sources, the modeling formula is

$M C R=M C R_{\text {ecolo }}-M C R_{\text {const }}$

where $M C R_{\text {ecolo }}$ and $M C R_{\text {const }}$ denote the $M C R$ of expansion of ecological land and constructed land, respectively.

A land unit in the urban setting where $\triangle M C R<0$ signifies that the resistance in development of ecological land is less than that in expansion of constructed land, indicating that the protection of ecological land is easier, so this land unit should be classified as suitable ecological land. A land unit where $\triangle M C R>0$ signifies that the resistance in development of ecological land is greater than that in expansion of constructed land. Constructed land is easier to enlarge, so this land unit should be classified as suitable constructed land. When the land unit $\triangle M C R=0$, the land unit can be treated as an interlaced zone that is suitable for both construction and ecological land. The model can be used in a costdistance module in Esri's geographical information system ArcGIS.

\subsubsection{Model assumptions}

There are a number of model assumptions.

1) We divide land in an urban setting into two categories by its use: ecological land, which is land that is most suitable for ecological protection, and non-ecological land, which is land that is most suitable for construction.

2) To maximum ecological protection, ecological land requires expansion. To maximum social and economic benefits, nonecological land requires extensive expansion. These two processes interact with each other, with the challenge being to find the balance between suitable ecological land and nonecological land.

3) The expansion of ecological land can be promoted by important ecological factors of land (e.g., wetlands, rivers, green space), which in turn will restrict the expansion of non-ecological land. In other words, the same land could provide drivers or constraints under different processes.

4) The effect of the land is determined by whether promotion or restraint is identified by the MCR value under different sources of expansion and resistance. 


\subsubsection{Model variables}

2.3.3.1. Source selection. Source refers to the landscape type that promotes the development of ecological processes. Source may be composed of areas that need special protection or areas of existing habitat that require representative selection and can fully reflect the requirements of different land-use habitat types. During the MCR calculation, the input of the source grid can be a patch or a combination of patches, and the source grid can be connected or unconnected in space. The plane expansionary source was used in this research as a source grid, and all non-source grids were designated NODATA (i.e., no value).

We used constructed land from the 2006 land-use classification map that we interpreted as the expansion source of constructed land (Fig. 4a). The expansion source of ecological land comprises land considered to have abundant biodiversity and ecosystem services and usually contains low-intensity farmland, wetlands, drinking water sources, major lakes and rivers, and greenbelt zones. In Changzhou this expansion source includes drinking water sources from the Yangtze River in the Wei Village waterworks; the protected area of the clear water canal in the New Menghe River; important wetlands and the confluence of the main stem rivers in Changzhou, the Yangtze River, Taihu Lake, and Gehu Lake (e.g., Yangtze export in the Desheng and Zaojiang rivers, Gangjiao, Taige, Furong City, and Songjian Lake); important mountains, natural landscape reserves, and important urban green space (e.g., Qingtian Mountain, Shun-guo Mountain, non-commercial forest of Hengshan Mountain, China Dinosaur Park, Yancheng City, and Qingfeng Park) (Fig. 4b).

2.3.3.2. The setting of the resistance plane. Land use in the urban setting can be viewed as competitive control and a coverage process of space, both of which must be achieved by overcoming resistance. The spatial heterogeneity of the land determines the different land units with different resistance coefficients, which constitute a resistance plane of the space. A resistance plane contains location and orientation factors of landscape elements and a resistance coefficient of landscape elements for land expansion. The resistance coefficient represents the level of difficulty of some land patch becoming a certain land type through the effect of environmental factors.

For this study, the selection of the resistance plane primarily came from the land cover map and then from elevation, slope, soil geology, distance from rivers and reservoirs and other water sources, and other environmental factors. The resistance of various elements of the land varies for different types of land and is reflected by the resistance coefficient, which is a relative value not an absolute value. We used 1-5 to represent the different levels of resistance, with 1 being lowest and 5 being highest, which is a subjective determination and not calculated by the MCRM (Liu et al., 2010). For the selection of suitable factors of the resistance plane for different sources, we considered five aspects of the geography of Changzhou: landscape type, engineering geology, vegetation coverage, distance from water bodies, and the dominant ecosystem service. From these we selected available factors to compose the resistance plane for the constructed land and ecological land.

Landscape type and engineering geology are inherent properties of the land. Landscape type can reflect land use so can more clearly reflect the feasibility of one landscape type transforming into another type. For example, water bodies are an important component of ecological land with a large value in ecosystem services (Daily, 1997) and should be protected, not over-exploited; therefore, this component has less resistance to the expansion process of ecological land and a greater resistance to the expansion process of constructed land. We divided landscape type into four categories - farmland, water, forest, and constructed land - based on land classification. Engineering geology reflects the ease of building in a region with one land type; hard ground is more appropriate for constructing, while soft ground should be protected as it is easier to lose through erosion. For engineering
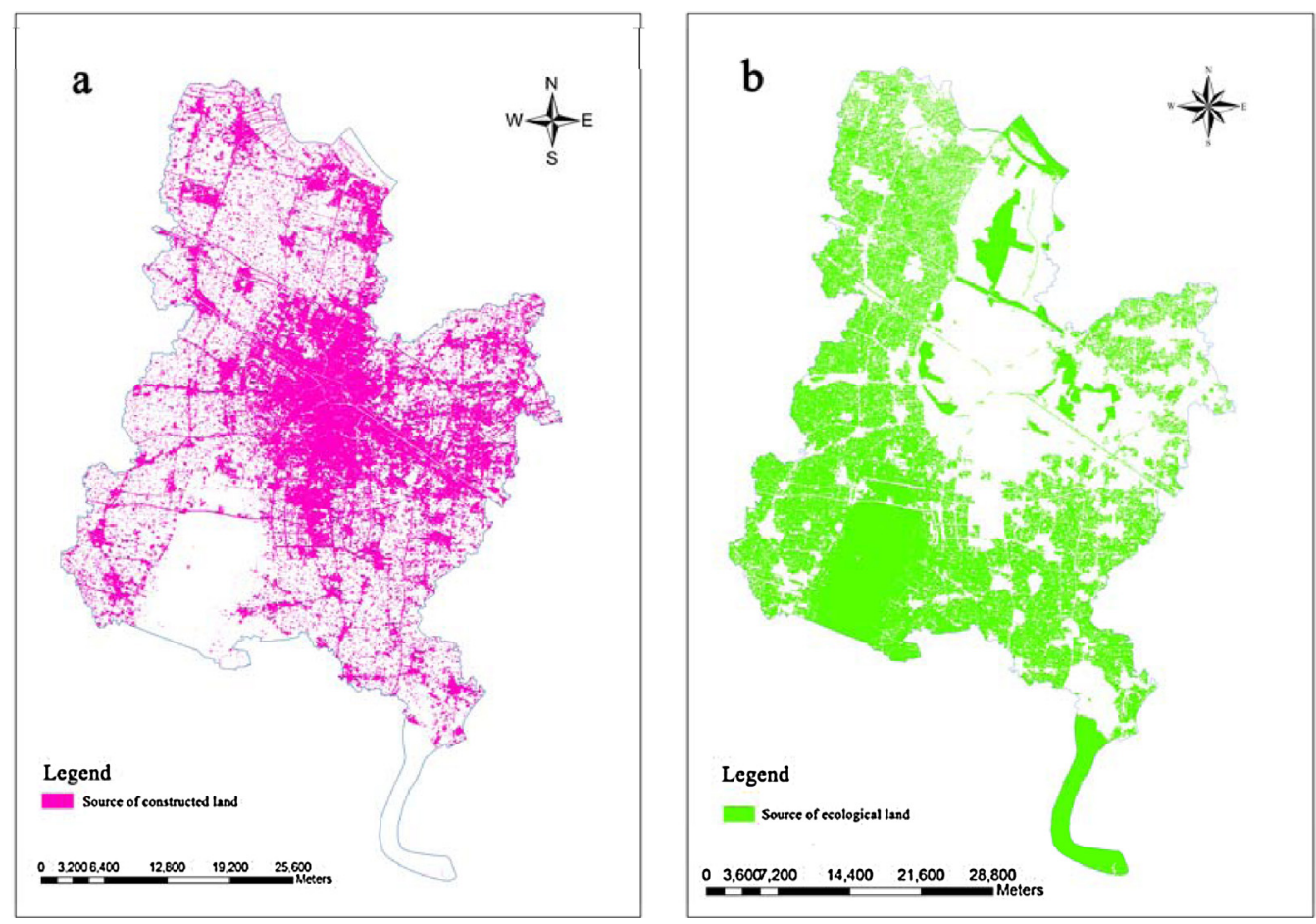

Fig. 4. Source of (a) constructed land and (b) ecological land in the Changzhou urban area. 
geology we used the "Evaluation Map of Master Plan-Engineering Geology in Changzhou City (2004-2020)" (Changzhou Planning Bureau, 2004).

Vegetation coverage denotes the density of local vegetation and reflects the important ecological effects of vegetation on the urban ecological system. High-density vegetation coverage can provide numerous ecosystem functions and has a low resistance value to ecological land, so it is easy to protect. Vegetation coverage and distance from water bodies are geographic characteristics of the land. Vegetation coverage is measured in remote sensing imagery by the normalized difference vegetation index (NDVI). For distance from water bodies, we took into consideration the characteristics of the rivers and lakes in Changzhou and categorized these into five groups: $0-30 \mathrm{~m}, 30-60 \mathrm{~m}, 60-120 \mathrm{~m}, 120-180 \mathrm{~m}$, and $180 \mathrm{~m}$ or more. The NDVI and the distance from water bodies were then analyzed using a classification matrix.

The dominant ecosystem services (e.g., water supply, flood control and drainage, water purification, $\mathrm{CO}_{2}$ absorption, and $\mathrm{O}_{2}$ release, Maintaining biodiversity, biomass production) can reflect the importance of the regional ecology. The region with abundant natural ecosystem services should be protected to maintain the ecological balance of the city where it has a greater resistance value to the expansion progress of constructed land.

2.3.3.2.1. Resistance plane of constructed land. We evaluated the resistance to constructed land transformation by taking into consideration four aspects: landscape type, engineering geology, vegetation coverage, and distance from water bodies. Specific values for these aspects are listed in Table 1.

2.3.3.2.2. Resistance plane of ecological land. We evaluated the resistance to ecological land transformation by considering four aspects: landscape type, vegetation coverage, distance from water bodies, and the dominant ecosystem service. Although three of these were also used to assess constructed land, the dominant ecosystem service is a different function specific to ecological value and is determined by a different land type. The specific values are listed in Table 2.

\section{Results}

\subsection{Resistance plane of both constructed land and ecological land}

Expansion of urban land is a competitive control process that needs to overcome landscape resistance to achieve landscape control. For example, ecological land achieves protective expansion by identifying and expanding important natural ecosystems, while constructed land must overcome resistance to different types of ecological land to achieve expansion. These processes occur at the landscape level. There are many models that describe landscape-level ecological processes. MCRM shows good performance on landscape-level connectivity, so we chose MCRM to simulate the expansion process of ecological land and constructed land in order to calculate the area of suitable ecological land from the balance of the two processes.

The resistance plane of ecological land or constructed land reflects the minimum cumulative resistance value for each land unit transforming into its source ecological land or constructed land. As the resistance value increases, the likelihood of successful transformation from original land into its source land decreases; in contrast, a smaller resistance value increases the likelihood of successful transformation.

The resistance value of ecological land in Changzhou City is between 0 and 11,145.4 (Fig. 5). The land with high values of resistance, which indicate an advanced level of constructed development, is mainly distributed in the old city and near the northern industrial area along the river where little ecological land is present; hence, it is less likely to transform into ecological land. The land with less resistance, which indicates a lower level of constructed development, is mainly spread around the center of Zhonglou, Tianning, and Qishuyan districts, while the rest is scattered in other districts and is connected by the road network (e.g., some towns in Xinbei District and Wujin District).

The resistance value of constructed land in Zhonglou District, which is mainly from basic farmland and the canal river system, is low with a maximum value of 756.559 . The area with a greater resistance value is mainly around Gehu Lake and Taihu Lake in Wujin District. The lakes have a maximum resistance value of $20,460.55$, reflecting the function of water bodies in urban ecological balance and the important service function that water bodies provide despite having a limited area. Land with a greater resistance to construction (values ranging from 150 to 4126) in Xinbei District consists mainly of wetlands along rivers and basic farmland. Water bodies in Qishuyan and Tianning districts that have a greater resistance to constructed land are scattered along the river system.

The city of Changzhou, which incorporates Gehu Lake and part of Taihu Lake, is located upstream of the Taihu Lake basin, and its northern region is near the Yangtze River. There are three drinking water source protection areas and some wetland reserves along the river in Changzhou, all of which contribute to the wetland ecosystem services that are important for maintaining a stable urban ecosystem. Hence, water body resistance to being transformed into constructed land ranged from values of 1000 to a maximum of $20,488.8$, indicating a high resistance to constructed land expansion. The resistance of farmland transforming into constructed land ranged from 100 to 1000 . Farmland often has a regular distribution, so the constraint of basic farmland is another important resistance factor to constructed land expansion. In summary, basic farmland and water bodies are major resistance

\section{Table 1}

The value system for resistance factors to constructed land.

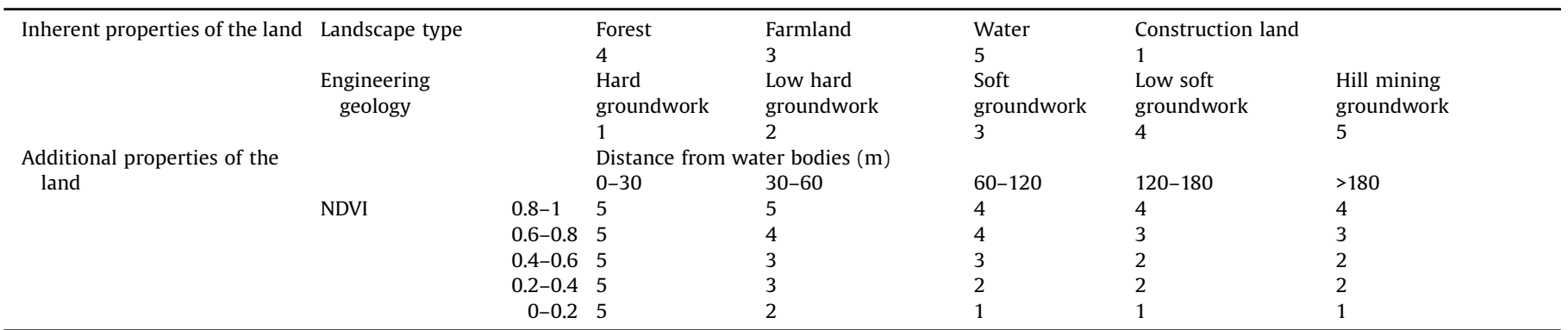

NDVI: normalized difference vegetation index. We used 1-5 to represent the different levels of resistance, with 1 being lowest and 5 being highest, which is a subjective determination and not calculated by the MCRM (minimum cumulative resistance model) (Liu et al., 2010). 
Table 2

The value system for resistance factors to ecological land.

\begin{tabular}{|c|c|c|c|c|c|c|c|}
\hline \multirow[t]{4}{*}{$\begin{array}{l}\text { Inherent } \\
\text { properties of } \\
\text { the land }\end{array}$} & \multirow{2}{*}{\multicolumn{2}{|c|}{$\begin{array}{l}\text { Landscape } \\
\text { type }\end{array}$}} & 3 & 4 & Water & $\begin{array}{l}\text { Construction } \\
\text { land } \\
5\end{array}$ & \\
\hline & & & & & & & \\
\hline & \multirow{2}{*}{\multicolumn{2}{|c|}{$\begin{array}{l}\text { Engineering } \\
\text { geology }\end{array}$}} & Hard groundwork & Low hard groundwork & Soft groundwork & $\begin{array}{l}\text { Low soft } \\
\text { groundwork }\end{array}$ & $\begin{array}{l}\text { Hill mining } \\
\text { groundwork }\end{array}$ \\
\hline & & & 5 & 4 & 3 & 2 & 1 \\
\hline \multirow[t]{9}{*}{$\begin{array}{l}\text { Additional } \\
\text { properties of } \\
\text { the land }\end{array}$} & \multirow[t]{4}{*}{$\begin{array}{l}\text { Dominant } \\
\text { ecosystem } \\
\text { service }\end{array}$} & & $\begin{array}{l}\text { Water supply, flood control and drainage, water } \\
\text { purification, } \mathrm{CO}_{2} \text { absorption, and } \mathrm{O}_{2} \text { release }\end{array}$ & $\begin{array}{l}\text { Maintaining } \\
\text { biodiversity, biomass } \\
\text { production }\end{array}$ & $\begin{array}{l}\text { Providing land for } \\
\text { human habitation }\end{array}$ & - & \\
\hline & & & 1 & 3 & 4 & 5 & \\
\hline & & & Distance from water bodies(m) & & & & \\
\hline & & & $0-30$ & $30-60$ & $60-120$ & $120-180$ & $>180$ \\
\hline & \multirow[t]{5}{*}{ NDVI } & $0.8-1$ & 1 & 1 & 2 & 2 & 2 \\
\hline & & $0.6-0.8$ & 1 & 2 & 2 & 3 & 3 \\
\hline & & $0.4-0.6$ & 2 & 3 & 3 & 4 & 4 \\
\hline & & $0.2-0.4$ & 2 & 3 & 4 & 4 & 4 \\
\hline & & $0-0.2$ & 3 & 4 & 5 & 5 & 5 \\
\hline
\end{tabular}

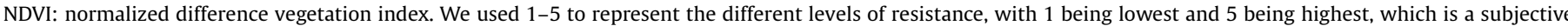
determination and not calculated by the MCRM (minimum cumulative resistance model) (Liu et al., 2010).

factors to the expansion of constructed land, which is consistent with the valuation of ecosystem services. That water bodies can provide more than $40 \%$ of the ecosystem service's value indicates that water plays a strong role in the city's ecological balance ( $\mathrm{Li}$ et al., 2014).

\subsection{Distribution characteristics of suitable ecological land}

\subsubsection{Overall distribution characteristics}

The total area of suitable ecological land in Changzhou is $1006.9 \mathrm{~km}^{2}$, which accounts for $53.8 \%$ of the total land area of the city. Suitable ecological land is mainly located in Wujin and Xinbei districts. Because water has a greater negative value of resistance, water is the most suitable landscape type for expansion of ecological land; hence, Wujin District, in the southern part of the city, has a greater expansion space for suitable ecological land compared to the other districts (Fig. 6). The central part of the city is suitable for the development of constructed land and has little space for the development of ecological land.

The percentage of ecological land in Changzhou City in 2006 was $65.1 \%$. Based on the demand for ecosystem services and combined with domestic and international trends ( $\mathrm{Li}$ et al., 2014), the percentage of ecological land in Changzhou City should be maintained at $60 \%$ or more in future growth in order to maintain a good urban landscape structure and ecological security. Land-use policy needs to be adjusted in order to balance urban ecosystem health with economic development and protection of ecological land.

\subsubsection{Regional distribution characteristics}

The proportion of suitable ecological land is much lower than that of suitable constructed land in Qishuyan, Tinian, and Zhonglou
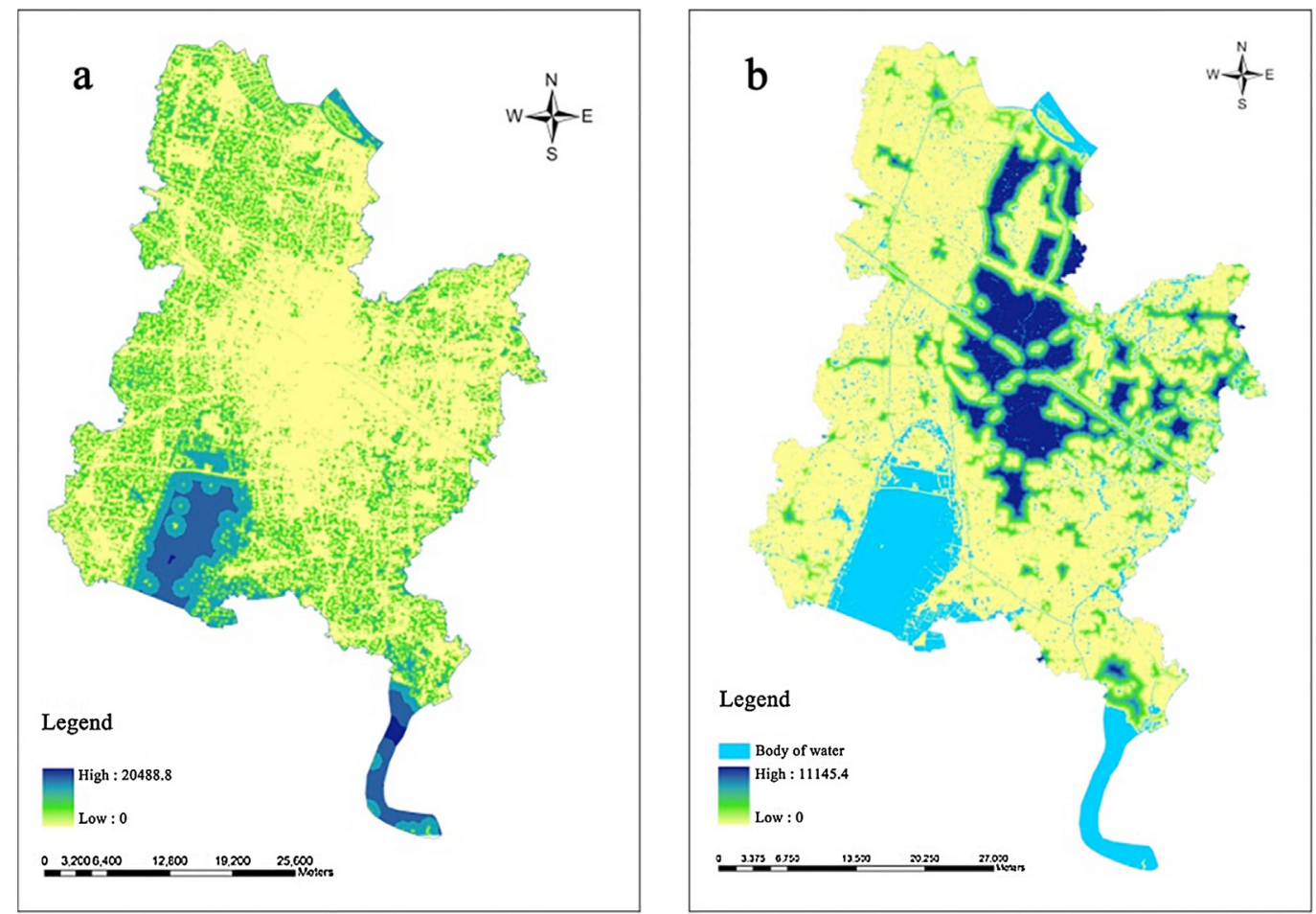

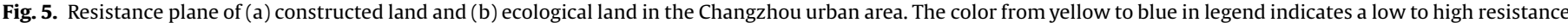

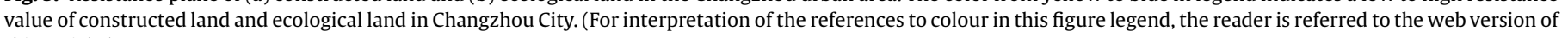
this article.) 


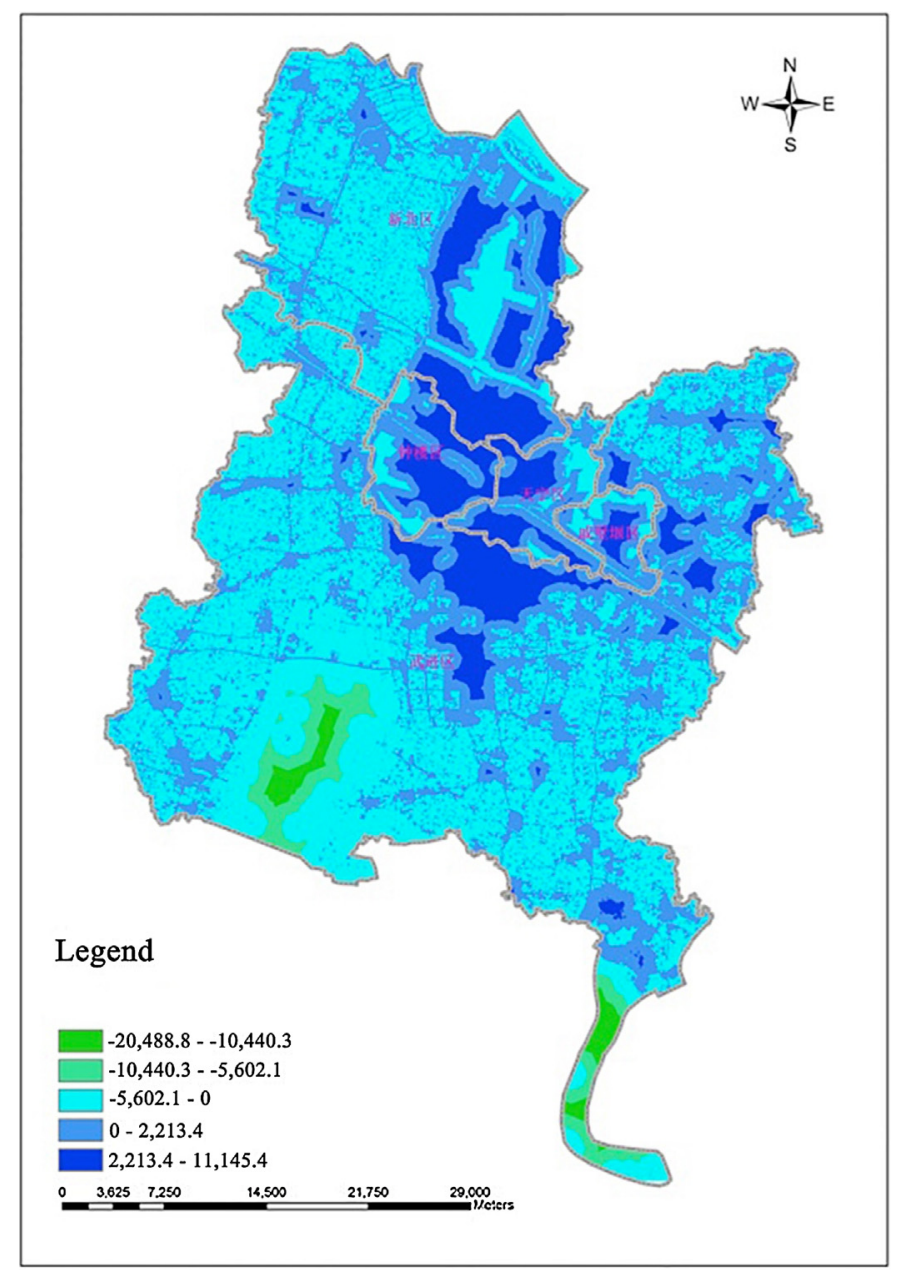

Fig. 6. Distribution of suitable ecological land in the Changzhou urban area. The color from green to blue in the legend indicates a suitable possibility from ecological land to constructed land in Changzhou City. Land with a value below 0 is suitable as ecological land, while land with a value above 0 is suitable as constructed land. (For interpretation of the references to colour in this figure legend, the reader is referred to the web version of this article.)

districts. Because Zhonglou and Tianning districts are part of the old town and have a higher proportion of built-up areas, they have less suitable ecological land area at $7.9 \%$ and $11.6 \%$, respectively. In those districts, the major protected area of ecological land is mainly along the canal river system. Wujin District has a higher proportion of suitable ecological land (61.5\%), which is $23.1 \%$ higher than the proportion of suitable constructed land. Gehu and Taihu lakes occupy a major area of suitable ecological land in this district, while the rest is mainly farmland or woodland in county towns. That the value of suitable ecological land is generally higher in Wujin District, which is close to Zhonglou and Tianning districts. Suitable ecological land in Xinbei District is about $146.2 \mathrm{~km}^{2}$, accounting for $47.9 \%$ of the total land area, and is mainly farmland and wetlands along the river (Table 3; Fig. 7).

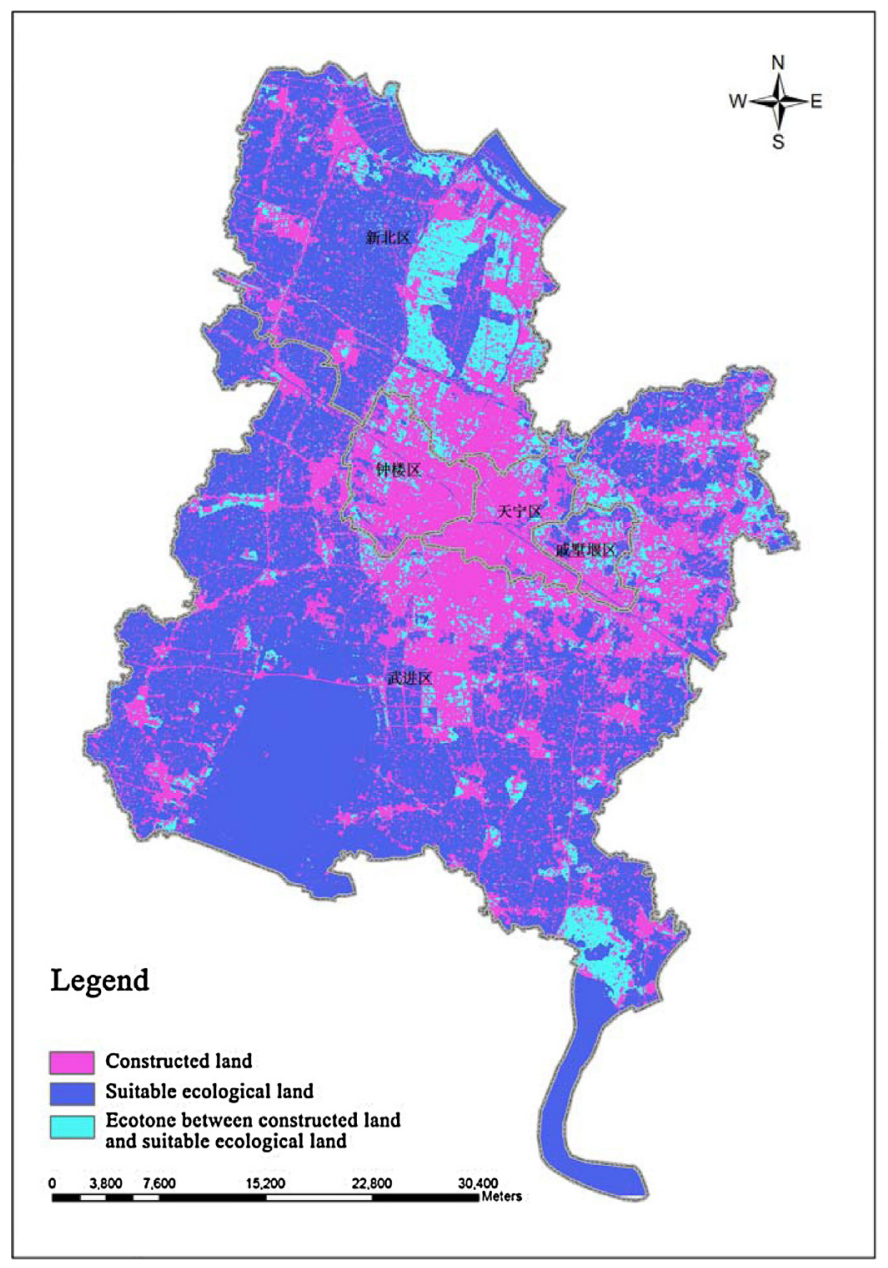

Fig. 7. Construction land, suitable ecological land, and ecotones in the Changzhou urban area.

\section{Discussion}

\subsection{Coordination of ecological land protection and constructed land}

For urban land, the protection of ecological land and the expansion of constructed land are co-existent processes. Ecological land refers to the land-use type that mainly provides ecosystem services and usually includes farmland, woodland, and water bodies. The dynamic change in ecological land area is the main driver of changes in urban ecosystem services. Studies on the spatial structure, service function, and appropriate amount of ecological land can reflect the functional strength of urban ecosystem services and urban ecological carrying capacity. Putting forward the concept of suitable ecological land helps in the calculation of the spatial range of ecological land needed to meet the minimum requirements of a healthy urban environment as well as facilitates urban planners to solve the conflicts between

Table 3

Proportion (\%) of constructed land, suitable ecological land, and transitional land in five districts of the Changzhou urban area in 2006.

\begin{tabular}{|c|c|c|c|c|c|}
\hline Land type & Qishuyan & Tianning & Zhonglou & Xinbei & Wujin \\
\hline Constructed land & 70.7 & 81.8 & 84.8 & 50.2 & 38.4 \\
\hline Suitable ecological land & 21.4 & 11.6 & 7.9 & 47.9 & 61.5 \\
\hline Ecotone & 7.9 & 6.6 & 7.3 & 1.8 & 0.1 \\
\hline
\end{tabular}


urban development and protection of ecological land in order to maintain a stable urban ecosystem.

\subsection{Strategies for protection of suitable ecological land}

The value of suitable ecological land ranges from $-20,488.8$ to -500 (Fig. 6) and includes mountains, lakes, rivers, natural landscape protected areas, wetlands, and other urban greenbelt areas. The Yangtze River is near an important domestic water intake, and both Taihu Lake and Gehu Lake play an important role in maintaining regional ecological balance and the conservation of biodiversity. Other low mountain or hilly areas include Qingtian Mountain and Shun-guo Mountain, which have important ecosystem services and are also important to Changzhou. In addition, basic farmland plays an important role in food security, biodiversity maintaining, pollination and constitutes a significant part of ecological land.

The protection of these areas requires not only conserving existing ecological land but also focusing on ecological buffer belts around urban built-up areas and improving ecological land service performance. There are a number of measures that could be considered to achieve improved protection. Setting up a protected green corridor along the Yangtze River would be beneficial for the protection of the ecological environment around urban water intakes. At the same time, a protected green belt around the industrial area next to the river could help prevent the spread of industrial air pollution. A prohibition on development of areas in and around important ecological landforms, such as Taihu Lake, Gehu Lake, important wetlands, hills, mountains, and other areas, is also needed. The establishment of country forest parks combined with the existing natural resources would protect the environment and improve the quality of life of urban residents. Large urban and country parks through Yancheng City, Songjian Lake, and other existing open spaces could improve the deficiencies of public green space in the urban core area. Building ecological networks by combining historical and cultural landscape protection areas that include the old trees of Changzhou could achieve environmental protection, ecological stability, and enhance the value of urban open space.

Land with a suitable ecological land value ranging from -499 to 0 (Fig. 6) tends to be spread around the edge of Taihu Lake, Gehu Lake, other natural reserves, and outside the city center. These lands, with characteristics of rapid outward expansion and low land-use efficiency, belong to the fringe areas of urban development and play an important buffering function in maintaining the ecological environmental quality of natural reserves and water resources of Taihu and Gehu lakes. This land thus improves material flow, energy flow and information flow of urban ecosystems.

The construction of ecological protection zones of green corridors along rivers and roads (Xinmeng River, Desheng River, Zaohong River, Taige Canal, the New Canal, railways, ShanghaiNanjing Expressway, and Changcheng-Changning Expressway) not only effectively connects the natural resources but also improves ecosystem services within the region and helps to control the large disordered expansion of construction space. Establishing buffer greenbelts on both sides of roads and rivers within the region and strengthening the functional connection of ecological space through integrative green space planning could reduce the urban heat island effect, control soil erosion, and filter contaminants. Building a hydrophilic park suitable for public events would increase the recreational functions of ecological space. Removing the buildings and structures in the urban areas with important ecosystem service, guiding the development of urban space, and avoiding disordered growth, loss of arable land, and low land-use efficiency will help to restrain construction space expansion, especially at the city's edge.
Land with a value above 0 (Fig. 6) is suitable as constructed land; this mainly includes Changzhou City center, the main industrial areas, and towns. As land resources have been developed and available open space within the region is limited, the assessment of ecological land-use effectiveness is essential. Improving construction land-use efficiency by reconstructing the old city and intensifying land use will help to prevent unnecessary expansion. At the same time, improving control and isolation of pollutants will help to reduce the potentially dangerous environmental contamination of local ecological land.

Water bodies are the major land-use type suitable for ecological land expansion. However, because of its capacity for biomass productivity and the protection afforded by legislation, basic farmland is the most suitable for the development of ecological land. On the other hand, restoring constructed land to ecological land has a greater resistance and therefore a lower possibility. Thus, we should strengthen the protection of existing ecological land and avoid the expansion of constructed land that may make ecological land unrecoverable.

To sustain and improve the urban ecological land and the ecosystem services it provides, we recommend the following specific advices: (i) enhancing the integration of urban wetlands (analogous to a city's kidneys), with green land (analogous to a city's lungs), gray land, pollution exits, and ecological corridors at the ecosystem level. (ii) Increase of the diversity of plants in the wetlands to follow the seasonal changes in a natural wetland and enhance the city's "kidney" and "lung" functions. (iii) Improvement and restoration of the ecological functions of wetlands to revitalize the water ecology of urban areas. (iv) Integration of permeable green space that allows water to re-enter the hydrological cycle and flood-retention ponds with multi-layer wetlands should be encouraged wherever possible.

\section{Conclusions}

We used the MCRM to select landscape type, engineering geology, vegetation coverage, distance from water bodies, and the dominant ecosystem service from inherent properties and additional properties of land in Changzhou. With this information we built a resistance evaluation system to identify suitable ecological land that could be used in coordinating development between the urban economy and ecology.

Our results showed that suitable ecological land in Changzhou accounts for $53.8 \%$ of the total land area of the city; in addition, there is still a small amount of constructed land available. To satisfy the needs of constructed land in an area of rapid urbanization and to protect suitable ecological land that provides important ecosystem services, a reasonable allocation of both areas and a suitable spatial pattern of the two land-use types are important.

For suitable ecological land, measures must be taken to actively protect the land and to restrict development. For ecological land in the ecotone, protection is primary, but controlling the degree of development and ensuring landscape connectivity and spatial integrity of critical ecological land are also needed. For suitable constructed land, rational development is needed along with increasing the intensity of land use.

In this research we used Landsat remote sensing data to obtain a land-use classification map of Changzhou. Because of the accuracy limits of supervised classification of remote sensing data, there will be a certain discrepancy between the classification image and reality. In addition, determining the selection factors and weight allocation of the resistance plane in the MCRM has some subjective elements, despite the use of an expert scoring mechanism. At the same time, selection factors are less comprehensive because of the limitations of information and data collection in Changzhou. 


\section{Acknowledgements}

This research was funded by the National Natural Science Foundation of China (No. 71273254). We thank Dr. Denise Rennis, an environmental scientist and science editor with more than 25 years of experience, for editing and correcting the manuscript.

\section{References}

Adriaensen, F. Chardon, J.P., De Blust, G., Swinnen, E., Villalba, S., Gulinck, H., Matthysen, E., 2003. The application of 'least-cost' modelling as a functional landscape model. Landsc. Urban Plann. 64, 233-247.

Bai, W.Q., Zhao, S.D., 2001. An analysis on driving force system of land use changes. Resour. Sci. 23 (3), 39-41 (in Chinese).

Bohnet, I., Pert, P., 2010. Patterns, drivers and impacts of urban growth - a study from Cairns, Queensland, Australia from 1952 to 2031. Landsc. Urban Plann. 97 (4), 239-248.

Changzhou Municipal Statistical Bureau, 2012. Changzhou Statistical Yearbook 06. Changzhou Municipal Statistical Bureau, Changzhou, China, pp. 2011.

Changzhou Planning Bureau. 2004. Evaluation Map of Master Plan-Engineering Geology in Changzhou City (2004xps2\#2020).

Chen, Chen, G.Q., 2007. Modified ecological footprint accounting and analysis based on embodied exergy - a case study of the Chinese society 1981-2001. Ecol. Econ. 61 (2), 355-376.

Chen, G.Q., Chen, Z.M., 2010. Carbon emissions and resources use by Chinese economy 2007: a 135-sector inventory and input-output embodiment. Commun. Nonlinear Sci. 15 (11), 3647-3732.

Chen, S.Q., Chen, B., 2012. Network environ perspective for urban metabolism and carbon emissions: a case study of Vienna, Austria. Environ. Sci. Technol. 46 (8), 4498-4506.

Chen, Q., Shi, P.J., 2005. Discussion on functional land use classification system. J. Beijing Norm. Univ. (Nat. Sci.) (in Chinese).

Chen, L.D., Fu, B.J., Zhao, W.W., 2006. Source-sink landscape theory and its ecological significance. Acta Ecol. Sin. 26 (5), 1444-1449 (in Chinese).

Chen, B., Chen, G.Q., Yang, Z.F., Jiang, M.M., 2007. Ecological footprint accounting for energy and resource in China. Energ. Policy 35 (3), 1599-1609.

Chen, H., Chen, G.Q., Ji, X., 2010. Cosmic energy based ecological systems modelling. Commun. Nonlinear Sci. 15 (9), 2672-2700.

Chen, Z.M., Chen, B., Chen, G.Q., 2011. Cosmic exergy based ecological assessment for a wetland in Beijing. Ecol. Model. 222 (2), 322-329.

Chen, S.Q., Chen, B., Fath, B.D., 2014. Urban ecosystem modeling and global change: potential for rational urban management and emissions mitigation. Environ. Pollut. 190, 139-149.

Costanza, R., d'Arge, R., De Groot, R., Farber, S., Grasso, M., Hannon, B., Limburg, K., Naeem, S., O'Neill, R., Paruelo, J., 1997. The value of the world's ecosystem services and natural capital. Nature 387 (6630), 253-260.

Daily, G.C., Polasky, S., Goldstein, J., Kareiva, P.M., Mooney, H.A., Pejchar, L., Ricketts T.H., Salzman, J., Shallenberger, R., 2009. Ecosystem services in decision making: time to deliver. Front. Ecol. Environ. 7, 21-28.

Daily, G., 1997. Nature's Services: Societal Dependence on Natural Ecosystems Island Press, Washington DC.

Foley, J.A., DeFries, R., Asner, G.P., Barford, C., Bonan, G., Carpenter, S.R., Chapin, F.S Coe, M.T., Daily, G.C., Gibbs, H.K., Helkowski, J.H., Holloway, T., Howard, E.A. Kucharik, C.J., Monfreda, C., Patz, J.A., Prentice, I.C., Ramankutty, N., Snyde, P.K. 2005. Global consequences of land use. Science 309, 570-574.

Goldstein, J.H., Caldarone, G., Duarte, T.K., Ennaanay, D., Hannahs, N., Mendoza, G. Polasky, S., Wolny, S., Daily, G., 2012. Integrating ecosystem-service tradeoffs into land-use decisions. Proc. Natl. Acad. Sci. USA 109, 7565-7570.

Hutyra, L.R., Yoon, B., Cymerman, J.H., Alberti, M., 2011. Carbon consequences of land cover change and expansion of urban lands: a case study in the Seattle metropolitan region. Landsc. Urban Plann. 103, 83-93.

Jiang, M.M., Chen, B., 2011. Integrated urban ecosystem evaluation and modeling based on embodied cosmic exergy. Ecol. Model, 222 (13), 2149-2165.

Jiang, M.M., Zhou, J.B., Chen, B., Yang, Z.F., Ji, X., Zhang, L., Chen, G.Q., 2009. Ecologica evaluation of Beijing economy based on emergy indices. Commun. Nonlinear Sci. 14 (5), 2482-2494.

Jordan, F., Baldi, A., Orci, K.M., Racz, I., Varga, Z., 2003. Characterizing the importance of habitat patches and corridors in maintaining the landscape connectivity of a Pholidoptera transsylvanica (Orthoptera) metapopulation. Landsc. Ecol. 18 (1) 83-92.

Knaapen, J.P., Scheffer, M., Harms, B., 1992. Estimating habitat isolation in landscape planning. Landsc. Urban Plann. 23 (1), 1-16.

Kroll, F., Muller, F., Haase, D., Fohrer, N., 2012. Rural-urban gradient analysis of ecosystem services supply and demand dynamics. Land Use Pol. 29, 521-535.

Larondelle, N., Haase, D., 2013. Urban ecosystem services assessment along a ruralurban gradient: a cross-analysis of European cities. Ecol. Indic. 29, 179-190.

Li, F., Yang, W.R., Zhang, X.F., Wang, R.S., 2009. Urban ecological land and improvements of ecosystem servcies in Changzhou city, China. China Popul. Resour. Environ. 19, 343-347 (special issue).
Li, F., Ye, Y.P., Song, B.W., Wang, R.S., Tao, Y., 2014a. Assessing the changes in land use and ecosystem services in Changzhou municipality, People's Republic of China, 1991-2006. Ecol. Indic. 42, 95-103.

Li, Q., Dai, Q. Zhu, Q. Yang, G.S., Wu, S.H., 2014. Ecological connectivity changes and its pattern optimization during land consolidation based on minimal accumulative resistance model. Sci. Geogr. Sin. 34 (6), 733-739 (in Chinese).

Liu, J.Y., Liu, M.L., Zhuang, D.F., Zhang, Z.X., Deng, X.Z., 2002. Spatial pattern analysis on China's land use changes in recent years. Sci. China. (Ser. D: Earth. Sci.)

Liu, X.F., Shu, J.M., Zhang, L.B., 2010. Research on applying minimal cumulative resistance model in urban land ecological suitability assessment: as an example of Xiamen city. Acta Ecologica Sinica 0421-0428.

Lorenz, K., Lal, R., 2009. Biogeochemical C and N cycles in urban soils. Environ. Int. $35,1-8$.

Millennium Ecosystem Assessment (MEA), 2005. Chapter 27: Urban systems. Volume 1: Current state \& trends.

Millennium Ecosystem Assessment (MEA), Chapter 9: Changes in ecosystem services and their drivers across the scenarios. Volume 2: Scenarios. 2005

Ma, S.J., Wang, R.S., 1984. Social-economic-natural complex ecosystems. Acta Ecol. Sin. 1-9.

Nelson, E., Mendoza, G., Regetz, J., Polasky, S., Tallis, H., Cameron, D.R., Chan, K.M.A., Daily, G.C., Goldstein, J., Kareiva, P.M., Lonsdorf, E., Naidoo, R., Ricketts, T.H. Shaw, M.R., 2009. Modeling multiple ecosystem services, biodiversity conservation, commodity production and tradeoffs at landscape scales. Front. Ecol. Environ. 7, 4-11.

Nikolakaki, P., 2004. A GIS site-selection process for habitat creation: estimating connectivity of habitat patches. Landsc. Urban Plann. 68 (1), 77-94.

Pauleit, S., Ennos, R., Golding, Y., 2005. Modeling the environmental impacts of urban land use and land cover change - a study in Merseyside, UK. Landsc. Urban Plann. 71 (2-4), 295-310.

Qiu, J.X., Turner, M.G., 2013. Spatial interactions among ecosystem services in an urbanizing agricultural watershed. Proc. Natl. Acad. Sci. USA 110 (12), 149-12154.

Radford, K.G., James, P., 2013. Changes in the value of ecosystem services along a rural-urban gradient: a case study of Greater Manchester, UK. Landsc. Urban Plann. 109, 117-127.

Saura, S., 2010. Measuring connectivity in habitat mosaics: the equivalence of two existing network indices and progress beyond them. Community Ecol. 11 (2), 217-222.

Seto, K.C., Güneralp, B., Hutyra, L.R., 2012. Global forecasts of urban expansion to and direct impacts on biodiversity and carbon pools. Proc. Natl. Acad. Sci. USA 109, $16083-16088$

Shao, L., Wu, Z., Chen, G.Q., 2013. Exergy based ecological footprint accounting for China. Ecol. Model. 252, 83-96.

Singh, N.J., Yoccoz, N.G., Bhatnagar, Y.V., Fox, J.L., 2009. Using habitat suitability models to sample rare species in high-altitude ecosystems: a case study with Tibetan argali. Biodivers. Conserv. 18 (11), 2893-2908.

China's New Urbanization Planning (2014-2020) [in Chinese] 2014 http://www.gov. cn/zhengce/2014-03/16/content_2640075.htm

TEEB, 2010. The Economics of Ecosystems and Biodiversity: Mainstreaming the Economics of Nature: a Synthesis of the Approach, Conclusions and Recommendations of TEEB. UNEP, Geneva, Switzerland.

Viglizzo, E.F., Paruelo, J.M., Laterra, P., Jobbágy, E.G., 2012. Ecosystem service evaluation to support land-use policy. Agr. Ecosyst. Environ. 154, 78-84.

Wang, R.S., Hu, D., Wang, X.R., Tang, L.J., 2004. Urban Eco-Services. China Meteorological Press, Beijing, pp. 20-29 (in Chinese).

Wang, Yang, K.C., Bridgman, C.L., Lin, L.K., 2008. Habitat suitability modelling to correlate gene flow with landscape connectivity. Landsc. Ecol. 23 (8), 989-1000.

Wang, R.S., Li, F., Hu, D., Li, B.L., 2011. Understanding eco-complexity: socialeconomic-natural complex ecosystem approach. Ecol. Complex. 8, 15-29.

Wu, C.G., Zhou, Z.X., Wang, P.C., 2009. Evaluation of landscape connectivity based on least-cost model. Chin. J. Appl. Ecol. 20 (8), 2042-2048 (in Chinese).

Yang, Z.F., Jiang, M.M., Chen, B., Zhou, J.B., Chen, G.Q., Li, S.C., 2010. Solar emergy evaluation for Chinese economy. Energ. Policy. 38 (2), 875-886.

Yeh, C.T., Huang, S.L., 2009. Investigating spatiotemporal patterns of landscape diversity in response to urbanization. Landsc. Urban Plann. 93, 151-162.

Yu, K.J., Li, W., Li, D.H., Li, C.B., Huang, G., Liu, H.L., 2005. Suitability analysis of heritage corridor in rapidly urbanizing region: a case study of Taizhou city. Geogr. Res. 24 (1), 69-76 (in Chinese).

Yu, K.J., 1999. Landscape ecological security patterns in biological conservation. Acta Ecol. Sin. 19 (1), 8-15 (in Chinese).

Zhang, L.B., Li, W.T., Wang, W., Xiong, Y.J., 2008a. Research on space modeling for minimum urban ecological land based on GIS: a case in Shenzhen. J. Nat. Resour. 23 (1), 69-78.

Zhang, X.H., Zhang, H.W., Chen, B., Chen, G.Q., 2008b. Water resources strategic planning based on system dynamics- a case study of Tianjin city. Commun. Nonlinear Sci. 13 (10), 2328-2336.

Zhang, Y., Zhao, Y.W., Yang, Z.F., Chen, B., Chen, G.Q., 2009. Measurement and evaluation of the metabolic capacity of an urban ecosystem. Commun. Nonlinear Sci. 14 (4), 1758-1765.

Zhao, D., Li, F., Wang, R.S., Yang, Q.R., Ni, H.S., 2012. Effect of soil sealing on the microbial biomass, $\mathrm{N}$ transformation and related enzyme activities at various depths of soils in urban area of Beijing, China. J. Soils Sediments 12, 519-530. 